\title{
THE GOOD FAITH DEFENSE OF THE ROBINSON-PATMAN ACT: A NEW RESTRICTION APPRAISED*
}

Althougr the Robinson-Patman Act requires that a seller offer uniform prices to competing purchasers, it explicitly allows a seller several avenues of defense. ${ }^{1}$ The FTC and private litigants have had considerable success, however, in constricting these defenses. Mere proof of a differential in the prices charged purchasers in competition with each other leads to an almost insurmountable inference of injury to competition between them. ${ }^{2}$ And the burden of proving a cost justification-the exception for price cuts which "make only

*Enterprise Industries, Inc. v. The Texas Co., 136 F. Supp. 420 (D. Conn. 1955), rev'd on other grounds, 240 F.2d 457 (2d Cir. 1957), cert. denied, N.Y. Times, May 21, 1957, p. 57 , col. 1.

1. 49 Stat. 1526 (1936), 15 U.S.C. $\S \S 13-13 b, 21$ a (1952). Section 2 (a) provides:

"[I]t shall be unlawful for any person engaged in commerce, in the course of such commerce, either directly or indirectly, to discriminate in price between different purchasers of commodities of like grade and quality, where either or any of the purchases involved in such discrimination are in commerce, where such commodities are sold for use, consumption, or resale within the United States or any Territory thereof or the District of Columbia or any insular possession or any other place under the jurisdiction of the United States, and where the effect of such discrimination may be substantially to lessen competition or tend to create a monopoly in any line of commerce, or to injure, destroy, or prevent competition with any person who either grants or knowingly receive's the benefit of such discrimination, or with the customers of either of them: Provided, That nothing herein contained shall prevent differentials which make only due allowance for differences in the cost of manufacture, sale, or delivery resulting from the differing methods or quantities in which such commodities are to such purchasers sold or delivered. ..."

Section 2(b) provides:

"Upon proof being made, at any hearing on a complaint under this section, that there has been discrimination in price or services or facilities furnished, the burden of rebutting the prima-facie case thus made by showing justification shall be upon the person charged with a violation of this section, and unless justification shall be affirmatively shown, the Commission is authorized to issue an order terminating the discrimination: Provided, hozeverer, That nothing contained [herein] shall prevent a seller rebutting the prima-facie case thus made by showing that his lower price ... to any purchaser ... was made in good faith to meet an equally low price of a competitor...."

2. FTC v. Morton Salt Co., 334 U.S. 37, 46-47 (1948) ; Whitaker Cable Co. v. FTC, 239 F.2d 253 (7th Cir. 1956), affirming CCH TRADE REG. REP. 1954-55 Transfer Binder IT 25443 (1955) ; Moog Industries, Inc. v. FTC, 238 F.2d 43, 50-52 (8th Cir. 1956), affirming, CCH Trade REg. Rep. 1954-55 Transfer Binder $\Uparrow 25444$ (1955) ; Enterprise Industries, Inc. v. The Texas Co., $136 \mathrm{~F}$. Supp. 420, 422 (D. Conn. 1955), rev'd on other strounds, 240 F.2d 457 (2d Cir. 1957) ; P. Sorensen Mfg. Co., 3 CCH Trade Reg. ReP. If 26105 (FTC June 29, 1956) ; Fruitvale Canning Co., 3 CCH TRADE REg. ReP. If 26069 (FTC June 15, 1956) ; P. \& D. Mfg. Co., 3 CCH TRAde Reg. ReP. If 25969 (FTC 1956), petition for reciezi filed, 3 CCH TRAdE REg. REP. I 26113; C. E. Niehoff \& Co., CCH TRADE REG. REP. 1954-55 Transfer Binder đf 25467 (FTC 1955), modified and aff'd, 241 F.2d 37 (7th Cir. 1957). 
due allowance for differences in the cost of manufacture, sale, or delivery"has all but destroyed the utility of that defense. ${ }^{3}$

The last to withstand challenge has been the "good faith" defense of section $2(b){ }^{4}$ It provides that a seller may rebut a prima facie violation of section 2 (a) by showing that his "lower price ... was made in good faith to meet an equally low price of a competitor." Until recently, this defense had not been severely limited, ${ }^{5}$ despite attempts by the FTC to minimize it. ${ }^{6}$ However, in Enterprise Industries, Inc. v. The Texas Co., ${ }^{7}$ a federal district court read into

3. See Dirlani \& Kann, Fair Competition 122-23 (1954); Rowe, Price Differentials and Product Differentiation: The Issues Under the Robinson-Patman Act, 66 Y AIE L.J. 1, 21-23 (1956); authorities cited $i d$. at 21 n.91.

4. 49 STAT. 1526 (1936), 15 U.S.C. $\$ 13$ (b) (1952).

5. The courts have imposed some limitations on the defense. The seller may not meet a competitor's price which he knows or should know is illegal. FTC v. Staley Mfg. Co., 324 U.S. 746 (1945) ; Standard Oil Co. v. FTC, 233 F.2d 649, 653 (7th Cir. 1949) (dictum). Contra, Standard Oil Co. v. Brown, 238 F.2d 54 (5th Cir. 1956). The discrimination must be temporary, not part of a permanent pricing system, and defensive rather than aggressive. FTC v. Staley Mfg. Co., supra; C. E. Niehoff \& Co., init. decision, CCH TradE REG. REP. 1954-55 Transfer Binder II 25134 (1954), final order, CCH TRADE REG. REP. 195455 Transfer Binder II 25467 (FTC 1955), modified and aff'd, $241 \mathrm{~F} .2 \mathrm{~d} 37$ (7th Cir. 1957). The discrimination must meet a specific competitor's price and not merely competition in general. C. E. Niehoff \& Co., final order, CCH TRAdE REg. REp. 1954-55 Transfer Binder II 25467 (FTC 1955), modified and aff'd, 241 F.2d 37 (7th Cir. 1957). The defense is not available to a seller who, in violation of $\$ 2(d)$, discriminates in granting promotional allowances to his customers. Henry Rosenfeld, Inc., 3 CCH Trade REg. Rep. $\llbracket 26068$ (FTC June 29, 1956).

In addition, a proposal to limit the defense has gained considerable support in Congress. S. 11, 85th Cong., 1st Se'ss. (1957) ; S. 11, 84th Cong., 2d Sess. (1956) ; and H.R. 1840, 84th Cong., 2d Sess. (1956) (identical bills), adopted the position of the FTC which was rejected in Standard Oil Co. v. FTC, 340 U.S. 231 (1951). See note 6 infra. H.R. 1840 was passed by the House in the 84th Congress with only three dissenting votes. 102 Cong. Rec. 9040 (daily ed. June 11, 1956). For discussion of the bill, see id. at 9013-39.

6. The Commission's primary attacks on the good faith defense have occurred in its prolonged prosecution of Standard Oil of Indiana. Standard Oil, to meet a competitor's price, sold gasoline to four wholesalers in the Detroit area at a lower price than it charged retail dealers. The wholesalers passed on much of this saving to their customers who were then able to undercut the retail dealers purchasing directly from Standard Oil. The Commission originally held that $\S 2(\mathrm{~b})$ merely prescribed the sequence of evidence and was not a substantive justification of an otherwise illegal price discrimination. 41 F.T.C. 263 (1945), modified, 43 F.T.C. 56 (1946), aff'd, 173 F.2d 210 (7th Cir. 1949). On appeal, however, the Supreme Court held that $\$ 2(b)$ is a substantive defense to a charge of price discrimination and remanded the case for a finding on Standard Oil's good faith. 340 U.S. 231 (1951). Thereupon, the FTC found that Standard Oil was not acting in good faith because it knew that, but for the fact that $\S 2(b)$ afforded a defense, its price discriminations would be illegal under $\$ 2$ (a). 49 F.T.C. 923 (1953). At present this theory has not been accepted by the courts. 233 F.2d 649 (7th Cir. 1956), cert. granted, 352 U.S. 950 (1956).

7. 136 F. Supp. 420 (D. Conn. 1955).

On appeal the Second Circuit did not reach the substantive issue of the case since it dismissed the complaint, holding that the plaintiff had failed to prove the amount of its 
the good faith defense a restriction which promises to be of considerable importance in future litigation.

Plaintiff service station operator was one of numerous retailers who had contracted to buy gasoline exclusively from the defendant Texas Company. Located close to a city but on a well-travelled interstate highway, plaintiff's station competed primarily with nearby retailers on the highway for the business of transient motorists, and it also competed for local trade with stations selling Texaco and other brands off the highway. ${ }^{8}$ The defendant, spurred by a decline in sales due to a local retail price war, offered a price cut to both local and highway Texaco dealers in the gas war area who matched but did not undercut the prices of their principal competitors selling rival brands. ${ }^{9}$ The amount of the price cut offered each dealer was based on the prevailing neighborhood price. Since the prevailing prices in the city were lower than on the highway, Texaco sold gasoline to the dealers in the city at a lower price than it charged plaintiff. The district court held that by effecting this price differential between purchasers who competed with each other, the Texas Company had violated section 2(a) of the Robinson-Patman Act. ${ }^{10}$

Rejecting defendant's argument that the discrimination was justified under section 2(b), the court held that Texaco's price discrimination did not meet an equally low price of a competitor. ${ }^{11}$ Meeting an equally low price, the court reasoned, permits a seller to offer a discriminatory price cut only if his favored buyer has access to an equally low price of a competing seller. It does not permit a price discrimination when the competing offers converge only at a

injuries. 240 F.2d 457 (2d Cir. 1957). The district court had held that plaintiff's damages equalled the amount of the illegal differential which it had paid the defendant over the course of the price war. $136 \mathrm{~F}$. Supp. at 422-23. The circuit court, however, held that the essence of the violation of the act is the discrimination, not the overcharge. Accordingly, plaintiff must show a loss of profits on sales which it lost to competitors who had received defendant's discriminatory price cut.

The district court's pasition, however, is supported by some earlier cases. See Bruce's Juices, Inc. v. American Can Co., S7 F. Supp. 985 (S.D. Fla. 1949), aff'd, 187 F.2d 919 (5th Cir.), modificd on rehearing, 190 F.2d 73, 74 (5th Cir.), cert. dismissed, 342 U.S. 875 (1951) ; Elizabeth Arden Sales Corp. v. Gus Blass Co., 150 F.2d 988 (8th Cir. 1945) (possibly overruled by American Can Co. v. Russellville Canning Co., infra); Bruce's Juices, Inc. v. American Can Co., 330 U.S. 743, 757 (1947) (dictum); cf. Bigelow v. R.K.O. Radio Pictures, Inc., 327 U.S. 251, 263-66 (1946) (defendant must bear the risk of uncertainty in the computation of damages which his wrong has created). But see American Can Co. v. Russellville Canning Co., 191 F.2d 38, 55-56 (8th Cir. 1951); Sun Cosmetic Shoppe, Inc. v. Elizabeth Arden Sales Corp., 178 F.2d 150, 153 (2d Cir. 1949).

S. Ten per cent of plaintiff's customers were local motorists. District court's Finding of Fact, No. 23.

9. This pricing policy, the "Chicago Plan," was developed and used by Texaco in various price wars. See Hearings Before the Subcommittee on Retailing, Distribution, and Fair Trade of the Senate Committee on Small Business, 84th Cong., 1st and 2d Sess., pt. 3, at 391 (1956) ; Transcript of Record, pp. 107, 109, 114-15, 124, Enterprise Industries, Inc. v. The Texas Co., 136 F. Supp. 420 (D. Conn. 1955) ; Brief for Defendant, pp. 8-10, ibid.

10. 136 F. Supp. at 422.

11. Id. at 421. 
lower level of distribution in the buyer's buyer-the consumer. The FTC ${ }^{12}$ and the Senate Sub-committee on Retailing, Distribution and Fair Trade ${ }^{13}$ have endorsed this reasoning for the increased protection they believe it affords retail gasoline dealers affected by price wars $;^{14}$ and this interpretation of the good faith defense seems to be the basis of a current FTC prosecution. ${ }^{15}$ The court's holding, however, seems not only ill-designed to remedy the evils of the gasoline industry, but actually opposed to the policies of the Robinson-Patman Act and other antitrust legislation.

The Enterprise view of the good faith defense is in sharp contrast with that expressed by the Supreme Court in Standard Oil Co. v. FTC. ${ }^{61}$ In that case, the Supreme Court declared that section 2(b) should allow a seller to en-

12. See Hearings, supra note 9, at 450, 458. Previously, the FTC had sanctioned this type of competitive pricing. Reply Brief for Defendant, pp. 9-12, Enterprise Industries, Inc. v. The Texas Co., 136 F. Supp. 420 (D. Conn. 1955). See Informal Opinion of the Commissioner, 81 Cong. Rec. app. pt. 10, p. 2340 (1937) (seller may discriminate to enable its subsidiary corporation-purchaser to meet competitors' prices).

13. S. Rer. No. 2810, 84th Cong., 2d Sess. 20, 28-29 (1956).

14. This policy seems to have influenced the district court in Enterprise. The court rejected defendant's argument that, since the plaintiff operated a second station in the city and there accepted the price cuts which it was alleging to be illegal, it was in pari delicto and therefore barred from obtaining relief. The court implied that, if anything, retailers were the victims of price wars. $136 \mathrm{~F}$. Supp. at 423 . See note 9 supra.

15. Pure Oil Co., FTC Dkt. 6640, respondent's answer reported in FTC News Summary, Jan. 9, 1957.

Recent developments, however, may curtail the effect of the Enterprise interpretation. In reversing the district court the Second Circuit prescribed a stringent standard for proving damages which private litigants may be unable to meet. See note 7 supra. And the FTC may have difficulty enforcing cease and desist orders which are based on the Enterprise holding. In C. E. Niehoff \& Co. v. FTC, 241 F.2d 37 (7th Cir. 1957), appellant seller granted his customers discriminatory quantity discounts similar to those offered by his competitors. The seller failed to bring himself within the good faith defense, however, because these discriminations were not made to meet specific individual offers of competitors, but were part of his continuing price policy. The circuit court, although affirming the FTC's conclusion that these discriminations were illegal, postponed enforcement of the Commission's cease and desist order until the Commission issued similar orders against all of appellant's competitors. The court found that the industry was highly competitive and to prohibit one seller from granting discriminatory discounts similar to those granted by his competitors would cause him undue hardship. The Eighth Circuit, however, has held that it does not have the power so to modify the Commission's order. See Moog Industries, Inc. v. FTC, 353 U.S. 908 (1957), granting cert. to 238 F.2d 43 (Sth Cir. 1956). If Niehoff is widely accepted in the courts the FTC may have difficulty enforcing Enterprise against any seller who is forced, in economic self-defense, to discriminate illegally. $C f$. General Electric Co. v. Federated Dep't Stores, Inc., CCH Trade REG. ReP. (1055 Trade Cas.) $\{68098$ (E.D. Wis.) (similar restriction on the enforcement of fair trade. laws); Automotive Elec. Serv. Corp. v. Times Square Stores Corp., 175 Misc. 865, 24 N.Y.S.2d 733 (Sup. Ct. 1940) (same) ; Kline, Inc. v. Davega-City Radio Inc., 168 Mise. 185, 4 N.Y.S.2d 541 (Sup. Ct. 1938) (same) ; Schimpf v. Macy \& Co., 166 Misc. 654, 2 N.Y.S.2d 152 (Sup. Ct. 1938) (same).

16. 340 U.S. 231 (1951). See Comment, 19 U. Chi. L. Rev. 58 (1951); 99 U. PA. L. REv. 1037 (1951). 
gage in price discriminations which had injurious effects on the competition among his purchasers if attempted in economic self-defense to meet a competitor's equally low price. ${ }^{17}$ Clearly, a seller's need for a lower price in response to a decrease in his sales is the same whether the decrease occurs because his purchasers switch to a price cutting competitor or because they are unable to protect their share of the retail market from distributors of a rival product. ${ }^{18}$ Furthermore, discriminations such as those in Enterprise undertaken by a seller to help a buyer meet a competitor's price are less likely to injure competition in the buyer's resale market than are those approved in Standard Oil. The Robinson-Patman Act was enacted to protect buyers from price discriminations favoring large purchasers which enabled them to undercut their smaller competitors and rapidly enlarge their share of the market. ${ }^{19}$ Discriminations of the kind in Standard Oil may give such a purchaser some leeway in beating down the price of his suppliers, ${ }^{20}$ but the price discriminations outlawed in Enterprise cannot; for even if section $2(\mathrm{~b})$ is construed to permit the seller to meet his competition indirectly, to establish this defense

17. 340 U.S. at $246 \mathrm{n} .12,249-50$.

18. Even though it differentiates between these two situations, Enterprise's holding may not be as erratic as it seems. Despite the policy announced by the Supreme Court in Standard Oil, the good faith defense may become so limited as to become useless even in the Standard Oil situation. The requirement that sellers meet only lawful prices of competitors is one example of a limitation which conceivably might be expanded to destroy completely the good faith defense. At present the party alleging the violation of the act has the burden of proving that the price matched by the discriminator was illegal. C. E. Niehoff \& Co., init. decision, CCH TRAde REg. REP. 1954-55 Transfer Binder If 25134 (1954), final order, CCH TRADE REg. Rep. 1954-55 Transfer Binder fl 25467 (FTC 1955), modificd and aff'd, 241 F.2d 37 (7th Cir. 1957). Cf. Automatic Canteen Co. v. FTC, 346 U.S. 61 (1953); Report of the Attorney General's National Committee to Study the Antitrust Laws 181-82 (1955) (hereinafter cited Atr'y GEN. REP.). In view, however, of the small percentage of price differentials which have been justified before the FTC, see note 3 supra, the courts might well presume that any price which is differentiated is unlawful, thereby shifting the burden of proving lawfulness to the seller seeking to establish the good faith defense.

However, it is clear that the lawfulness requirement does not, at present, so restrict the defense. Moreover, there is a conflict in the circuits as to whether the price which is matched need be lawful at all. Compare Standard Oil Co. v. FTC, 233 F.2d 649 (7th Cir. 1956), with Standard Oil Co. v. Brown, 238 F.2d 54 (5th Cir. 1956). And in the light of the Supreme Court's holding in Standard Oil and its dictum in Automatic Canteen Co. v. FTC, 346 U.S. 61,74 (1953) that "it is our duty to reconcile [the Robinson-Patman Act] with the broader antitrust policies ... laid down by Congress," it is unlikely that the Court will allow the good faith defense to go the way of the cost justification. See note 3 sutra.

19. Austin, Price Discrimination and Related Problems Under the RobinsonPatMan Act 8-11 (1953); Machlup, Characteristics and Types of Price Discrimination, in Business Concentration and Price Policy 397, 412 (1955); Rowe, Price Discrimination, Competition, and Confusion: Another Look at Robinson-Patman, 60 YALE L.J. 929-31. (1951); DirlaM \& KahN, FaIr Competitton 206 (1954).

20. See Dirlam \& Kahn, Leadership and Conflict in the Pricing of Gasoline, 61 Yale L.J. 818, 848-49 (1952); ATT'Y GEN. REP. 185 (1955) (dissent of Walter Adams). 
defendant must show that the favored buyer is not aggressively expanding his share of the market, but merely meeting a competitor's price. ${ }^{21}$

Furthermore, although Enterprise has received strong support, ${ }^{22}$ it neither prevents price wars in the gasoline industry nor insulates retailers from their cost. $^{23}$ Price wars are characteristic of unstable oligopolies like the gasoline industry. ${ }^{24}$ Normally an oligopolist is reluctant to increase his sales by lowering his price since such an increase will significantly cut into the sales of competing firms who will in turn negate his gain by meeting his lowered price.25

21. See note 28 infra and accompanying text.

Since this interpretation of the good faith defense implies that the seller have some influence over the resale prices of his purchaser it may lead to a conflict with the Sherman Act's prohibitions against resale price fixing agreements. Although the courts might require the seller to show that his favored buyer is not an aggressive price cutter, he should not have to prove such control over the buyer as to violate $\S 1$ of the Sherman Act. Alternatively, if any control over the buyer's resale price is deemed illegal, the courts could require the seller only to prove that his price was lowered in economic self-defense; the retailer's use of the price advantage would thus be irrelevant. Cf. Automatic Canteen Co. v. FTC, 346 U.S. 61, 74 (1953). For further discussion of the relation of $\S 1$ of the Sherman Act to this situation see notes 42-46 infra and accompanying text.

22. See notes 12-13 supra and accompanying text.

23. It may be argued that the Robinson-Patman Act's prohibitions against price discriminations were not intended to protect small businesses from the effects of fierce competition among themselves. Admittedly, some commentators have viewed the act as outright class legislation designed to protect small competitors from the rigors of all types of competition. See, e.g., Adelman, The Consistency of the Robinson-Patman Act, 6 STax. L. REv. 3 (1953). However, in theory the act attempted to prevent, in their incipiency, conditions which would tend to destroy competition among buyers. E.g., Pataran, The RoBInson-P ATMAN ACT 11 (1938). Section 2(a)'s prohibitions against price discriminations which affect competition among purchasers from the discriminator were primarily designed to destroy the ability of large distributors to force discriminatory price concessions from their suppliers, which gave them a competitive advantage over even equally efficient distributors. See note 19 supra. While the act does proscribe discriminations which injure competition among sellers, here again it prohibits a competitive tactic which is generally available only to large distributors who sell in more than one market, and are thus able to charge their customers different prices. Edwards, MaIntaining Comspetitton 159 (1949). Cf. Dirlam \& Kann, Fair Competition 276 (1954). Only $\S 3$ 3's proscription of selling at an unreasonably low price would seem to be specifically concerned with the problems arising in a market with a large number of small sellers.

On the other hand, an attack on price wars may be rationalized as an attempt to protect effective competition. This has been the justification of the act's assault on the competitive advantages of the large buyer. See Patman, op. cit. supra at 11 . The possibility of a price war may tend to drive prices up. Fellner, Competirion Among the Few 183 (1949). Or, it may inhibit the entry of new sellers into a market, MACHLup, THE Econonirs of Sellers' Competition 236, 263, 519 (1952) ; and in the control of a powerful seller a price war may be a means of achieving monopoly power, Edwards, MaInTaIning CosPETITTON 169 (1949).

24. See S. Rep. No. 2810, 84th Cong., 2d Sess. 1-2 (1956) ; Cassady, Price Miaking and Price Begatior in the Petroleum Industry c. 15 (1954). For an analysis of oligopoly pricing generally, see Feliner, Competition Among the Few (1949) ; Machlut, The Economics of Seilers' Competition cc. 11-16 (1952) ; Bain, Price Theory passim (1952).

25. Machlup, The Economics of Sellers' Competition 470 (1952); Rostow, A National Poliç For the OIL Industry 12-13, 63 n.90, 76 (1948); Rowe, Price Dis- 
Frequently, however, an independent seller, eager to expand his market position, acquires an independent source of supply and undercuts his competitors, or a major refiner is forced to "dump" an excess supply by risking a temporary price cut. ${ }^{20}$ As a result, a price war is instigated in a limited area. ${ }^{27}$ Since the initial price cut which begins the war beats and not merely meets competitors' prices it would not be sheltered by even the broadest interpretation of the good faith defense. ${ }^{28}$

On the contrary, by narrowing the scope of section $2(\mathrm{~b})$, the decision aggravates the effect of price wars on retailers ${ }^{29}$ who are forced to cut their prices to maintain their volume of sales. ${ }^{30}$ Enterprise's sole effect is to prohibit suppliers from lowering their wholesale prices to help their retailers meet a competitor's price cut. ${ }^{31}$ While this may prevent retail prices

crimination, Competition and Confusion: Another Look at Robinson-Patman, 60 YALE L.J. 929, 938-39 (1951) ; CASSADY, op. cit. supra note 24, at 241.

26. For a detailed analysis of price wars in the gasoline industry see Cassady, op. cit. sitpra note 24; Brown, Mulvinill, Thompson \& Vineburgh, Report of Governor's Committee to Investigate the Gasoline Price War 6-10 (Hartford, Conn., Dec. 23, 1950).

27. Sellers able to do so will attempt to limit the scope of the price war to a fraction of their market by lowering their prices only to distributors who sell in a limited area. BaIn, Price Theory 431 (1952); authorities cited 66 YALE L.J. 243, 251 n.39 (1956); Rowe, Price Discrimination, Competition, and Confusion: Another Look at RobinsonPatmun, 60 Yale L.J. 929, 939 (1951); Berger \& Goldstein, Meeting Competition Under the Robinson-Patman Act, 44 ILL. L. REv. 315, 316 (1949).

Price wars most frequently occur in areas which are easily accessible by inexpensive muans of transportation from the supply of surplus gasoline, and which have a large potential consumption of gasoline. CASSADY, op. cit. supra note 24, at 268. See also, S. Ke.t. No. 2810, 84th Cong., 2d Sess. 3-5 (1956) (listing factors which contribute to the high frequency of price wars in New Jersey).

28. Balian Ice Cream Co. v. Arden Farms Co., 231 F.2d 356 (9th Cir. 1955) ; Samuel H. M sss, Inc. v. FTC, 148 F.2d 378, 380 (2d Cir.), cert. denied, 326 U.S. 734 (1945); Anheuscr-Busch Co., 3 CCH Trade Reg. Rep. II 26257 (FTC 1956) ; Adelman, The Consisteniy of the Robinson-Patman Act, 6 Stan. L. Rev. 3, 17 (1953); Edwards, Doing Business Under the Law in Delivered Pricing and the Future of Amrerican Business 36, 49 (1948) ; CCH Anti-Trust Symposium 36, 49 (1946) ; Berger \& Goldstein, Meeting Compitition Under the Robinson-Patman Act, 44 ILL. L. Rev. 315, 328 (1949). It might be argued, however, that such a price cut, even if discriminatory, is a spark of competition in an otherwise monopolistic industry and should not be prohibited. Machlup, Characteristics and Types of Price Discrimination in Business Concentration and Price Policy 397, 434 (1955) ; 66 YALE L.J. 243, 254 (1956).

29. At present the impact of price wars on retailers' profit margins is severe. See Brown, Miluvinill, Thonipson \& Vineburgh, op. cit. supra note 26 , at 8 .

30. Competing retail gasoline dealers are conscious of their rivals' prices. Cassady, op. cat. supra note 24, at 255-57. Accordingly, they will react to a price cut as oligopolists, see Machlup, The Economics of Selrers' Competition 508-09 (1952), and are likely to meet a competing retailer's prices exactly.

31. Refiners might cut their prices either because they believe the aggressive price cutter is attempting to secure permanently a larger market position, or because they also have excess inventory and are reluctant to accept even a temporary reduction in their sales volume. See CASSADY, op. cit. supra note 24 . Once competing sellers make the decision to match all price cuts and retain their share of the market, if the total demand 
from being driven as low as might otherwise occur, the full amount of these price cuts must now come out of the retailers' profit margin. And since the ability of the retail dealer to meet price cuts normally acts as a deterrent to aggressive price-cutting, Enterprise may even tend to encourage such practices. $^{32}$

Enterprise has implications which even more adversely affect the small retailer whom the Robinson-Patman Act was intended to protect, for it tends to foster vertical integration. If the decision is applicable to a seller because of his market position, he may either meet his competitors' prices with costly uniform price cuts-which may also spark a price war in another part of the seller's market-or allow his competitors to cut into his sales as much as they wish. However, a seller may avoid Enterprise by altering his distribution system and selling directly to purchasers who receive the lower price offers of competing sellers. He may then meet competitors by cutting his price only where necessary, ${ }^{33}$ avoiding further cuts into his profit margin as well as the risk of provoking additional price wars. The most practicable means of achieving this result will often be to integrate vertically. ${ }^{34}$ Relinquishing all control over retail dealers and throwing them open to competitors' price offerswhich the seller then can lawfully meet-is seldom a real possibility. Sellers

for gasoline in the price war area is sufficiently elastic all excess may be sold at the lower prices which will prevail. However, total sales may remain substantially the same, and a period of strength testing will then follow. For factors which will determine the outcome of such a deadlock see FEILNER, op. cit. supra note 23, at 24-33.

32. FELINER, id. at 177-79; RosTow, op. cit. supra note 25, at 76 .

Enterprise would prevent the aggressive price cutter's competitors from matching his price drops by discriminatory cuts, even when their favored and disfavored purchasers are not in competition with each other. It is unlikely that Congress intended so great a restriction of the good faith defense where competition among buyers was not affected. See Austin, Price Discrimination and Related Problems Under the Robinson-Patmian ACr 91-92 (1953). However, since such price discriminations necessarily affect competition among the sellers, the aggressive price cutter might himself initiate an action against the discriminators. Proof of the price differential alone might be sufficient to establish a prima facie case of discrimination. Samuel H. Moss, Inc. v. FTC, 148 F.2d 378 (2d Cir.), cert. denied, 326 U.S. 734 (1945). Cf. FTC v. Morton Salt Co., 334 U.S. 37, 46-48 (1948). But see Rowe, Price Differentials and Product Differentiation: The Issues Under the Robinson-Patman Act, 66 Y ALE L.J. 1, 39 n.155 (1956). While the difficulty of showing lost profits from an expected increase in business may foreclose the seller from recovery in a treble damage suit, $c f$. Comment, 65 Y ALE L.J. 992, 1014 (1956), he may file a complaint with the FTC, 38 STAT. 734 (1914), 15 U.S.C. $\$ 21$ (1952), or obtain an injunction from a federal district court, 38 Star. 737 (1914), 15 U.S.C. $\$ 26$ (1952).

33. Standard Oil Co. v. FTC, 340 U.S. 231 (1951).

34. When rapidly dropping prices increased the difficulties of administering price reduction schemes similar to the one used in Enterprise, many refiners selling in the New Jersey area approached this result by delivering gas to retailers on consignment and paying them a small commission for selling it. Hearings, supra note 9, at 289, 305, 349. Such a system may increase the cost of operating the retail outlets. Cf. CASSADY, op. cit. supra note 24 , at 237 n. 3 .

If the price cut is generated by an independent seller, see note 26 supra and accompanying text, his competitors always have the alternative of buying his business operation. 
who have distributed their products through exclusive-dealer retail outlets may be reluctant suddenly to relinquish all control of these outlets. ${ }^{35}$ Moreover, relinquishing control is not sufficient to avoid Enterprise. As that decision interprets the good faith defense, even a seller who sells to a completely independent buyer-retailer must show that a competing seller's equally low price was available to that purchaser. ${ }^{36}$ Thus the seller may lawfully meet only those competitors who choose to deal with his purchasers and cannot respond to the aggressive price cuts of an integrated wholesaler-retailer who may undercut him with impunity. ${ }^{37}$

In sum, by giving to the vertically-integrated distributor a competitive advantage unrelated to his performance, Enterprise frustrates the antitrust laws' attempt to promote efficiency. ${ }^{38}$ The decision, in addition, erects a barrier to backward shifting of the cost of retail price wars. ${ }^{39}$ Both this barrier and the stimulus to vertical integration will injure the small businesses which the Robinson-Patman Act harbors. The good faith defense should be read so as to avoid these incongruous results. The wholesaler should be allowed to set a price which will enable his retailer to meet the latter's competitors. Although perhaps not a literal interpretation of section $2(\mathrm{~b})$, this reading would subserve the policies of the act without running counter to its actual language. Furthermore, courts have not literally construed the phrase "to meet an equally low price of a competitor." Thus, a seller of a premium product may not cut his price to match exactly the price of a competing, lower-grade product. He may only engage in economically defensive price discriminations and must maintain the normal price differential between his price and that of his lower-quality competitor. ${ }^{40}$ In view of these liberties in determining the lawful dollar amount of a discrimination, there is ample reason for interpreting the good faith defense to allow a seller indirectly as well as directly "to meet an equally low price of a competitor." For it is clear that sellers of competing products are themselves competing even though they do not sell to the same retailers. ${ }^{41}$

35. Gasoline refiners, for instance, have always been conscious of the need for access to a sufficient number of well-located retail outlets, and have also felt that successful utilization of brand name good will requires that outlets sell exclusively one brand of gasoline. See CASSADY, op. cit. supra note 24 , at 237 . It is likely that most sellers in other industries who presently distribute through exclusive dealer outlets have similar reasons for retaining long-run control over them.

36. 136 F. Supp. at 421.

37. Such a result would, of course, encourage aggressive price cutting and market expansion by integrated sellers. See note 32 supra and accompanying text.

38. Cf. ATt'Y GEN. REP. $207-08$ (1955).

39. See text at note 31 supra.

40. Anheuser-Busch, Inc., 3 CCH TrAde Reg. Rep. I 26257 (FTC 1956) ; MinneapolisHoneywell Regulator Co., 44 F.T.C. 351, 396-97 (1948). See also Standard Oil Co. v. FTC, 340 U.S. 231, 247 n.12, 249, 250 (1951) ; Att'y Gen. Rep. 183-84 (1955). Cf. Porto Rican American Tobacco Co. v. American Tobacco Co., 30 F.2d 234 (2d Cir. 1929) (similar price discrimination held a violation of unamended $\S 2$ of the Clayton Act).

41. This was conceded by the district court in Enterprise. 136 F. Supp. at 421 . See also Pure Oil Co., FTC Dkt. 6640, respondent's answer reported in FTC News Summary, 
At first glance, the proposal outlined in text might seem inconsistent with the Sherman Act ;2 the discriminating seller might be required to enter into price fixing agreements with his favored purchasers before he can prove that he was indirectly meeting competition, and these contracts might be thought illegal per se under section 1 of the Sherman Act. ${ }^{43}$ But sellers should be able to satisfy the good faith requirement without going this far. Often the seller can justifiably presume that the recipients of a price cut will react rationally to the economic forces in their selling market and meet their competitors' price. ${ }^{44}$ And the seller may insure that they do, without making an illegal resale price maintenance agreement. He may avoid entering any agreement at all and still compel price matching by refusing to grant the discount to retailers who do not defend their share of the market in price wars. ${ }^{45}$ And even if the seller does

Jan. 9, 1957. Cf. Krug v. International Telephone and Telegraph Co., 142 F. Supp. 230 (D.N.J. 1956) (wholesaler and integrated wholesaler-retailer held to be in competition with each other).

Concededly, the good faith defense might be read to allow a seller to meet the price offered by a competing wholesaler to the latter's retailer. As a practical matter, however, a defendant may be unable to prove the wholesaler's price. In addition, if the competing wholesaler's price was illegal-it may often be discriminatory, see note 26 supra-such a reading might preclude the defendant from availing himself of the good faith defense altogether, see cases cited note 5 supra, even though he might be unable to meet the price cut in any other way. On balance, therefore, the seller should be allowed, for purposes of the good faith defense, to assume his retailer's position in the distribution chain.

42. 26 Stat. 209 (1890), 15 U.S.C. $\$$ 1-7 (1952).

43. E.g., United States v. Bausch \& Lomb Optical Co., 321 U.S. 707 (1944).

44. See note 30 supra.

45. A seller may lawfully establish a policy of refusing to deal with purchasers who do not resell his goods at his suggested price. United States v. Colgate \& Co., 250 U.S. 300 (1919) ; Frey \& Son, Inc. v. Cudahy Packing Co., 256 U.S. 208 (1921). Cf. FTC v. Raymond Bros.-Clark Co., 263 U.S. 565 (1924) (purchaser may lawfully refuse to deal with supplier because supplier sells to competitor of the purchaser). See Comment, 58 YALE L.J. 1121, 1125-29 (1949). This doctrine was reaffirmed in United States v. Bausch \& Lomb Optical Co., 321. U.S. 707, 729 (1944). In that case the Court held that defendant had entered into agreements to fix retail prices in violation of $\S 1$ of the Sherman Act. However, it refused to prohibit Bausch \& Lomb or its exclusive sales outlet from choosing its retail dealers in a manner calculated to protect the luxury character of their product.

The Colgate line of cases is, however, limited by a series of cases which find an implied agreement between the seller and his purchasers for resale when the seller's policy effectively restricts the resellers' pricing decisions. United States v. Bausch \& Lomb Optical Co., supra; FTC v. Beechnut Packing Co., 257 U.S. 441 (1922); United States v. A. Schrader's Sons, Inc., 252 U.S. 85 (1920). See Atr'y GeN. Rep. 15-16 (1955). It is not likely that these cases will be applied to the kind of conditional price discriminations required by the good faith defense. The sporadic nature of such discriminations, see note 5 supra, militates against their being considered illegal implied agreements. Harriet Hubbard Ayer, Inc. v. FTC, 15 F.2d 274 (2d Cir. 1926) (occasional instances of refusals to deal with purchasers, who resold at less than the seller's suggested price, do not constitute illegal implied agreements). Moreover, these conditional price discriminations do not totally restrict the re-seller's freedom to sell at whatever price he chooses. Since the recipient of the price cut is engaged in an oligopolistic price war, he may choose to forgo future low prices from his supplier and undercut his competitors in an effort to bring an end to the price war. See FELLNER, op. cit. supra note 23, at 24-33. 
enter into an agreement with his favored buyers, it need not be deemed a price fixing agreement which is illegal per se under the Sherman Act. For neither the purpose nor the effect of the agreement is to eliminate price competition in the retail market, but rather to enable the seller to compete with rival sellers without violating the Robinson-Patman Act. ${ }^{46}$

46. A contract which incidentally fixes a price is not an illegal per se price fixing agreement if its purpose is wholly unrelated to a restriction of competition. United States v. Morgan, 118 F. Supp. 621, 688-91 (S.D.N.Y. 1953) (resale price maintenance agreement incident to the distribution of a new security issue by a syndicate of underwriters and dealers held lawful), 63 Y ALE L.J. 399 (1954); Board of Trade v. United States, 246 U.S. 231 (1918) (agreement by members of Chicago Board of Trade to buy only at the closing market price during the hours when the market was closed held lawful). See United States v. Trenton Potteries Co., 273 U.S. 392 (1927) ("the aim and result of every price fixing agreement, if effective, is the elimination of one form of competition"). And it may be argued that the Sherman Act does not prohibit these pricing policie's, for their effect is not to fix resale prices but to require the re-seller to follow the competitive price in his market. See Appalachian Coals, Inc. v. United States, 288 U.S. 344 (1933); Chicago Board of Trade v. United States, supra. But see United States v. Socony-Vacuum Oil Co., 310 U.S. 150 (1940) (if the agreement is denominated a price fixing agreement, the fact that prices will still be set in part by market forces does not validate it).

It should be noted, however, that in granting a discriminatory price cut and entering into this agreement with his purchasers, the seller is attempting to secure his share of the market and force restoration of "normal" prices under an oligopolistic quasi-agreement. See note 31 supra. The legality under the Sherman Act of this purpose is unclear. See ATt'y GEN. Rep. 41-42 (1955) (dissent of Eugene V. Rostow). 